\begin{tabular}{|c|c|c|c|c|c|c|}
\hline $\begin{array}{c}\text { No. of Patients, Anaesthetic, } \\
\text { and Operation }\end{array}$ & $\begin{array}{l}\text { Fall in } \\
\text { B.P. }\end{array}$ & $\begin{array}{c}\text { Time of } \\
\text { Lowest B.P.* }\end{array}$ & $\begin{array}{l}\text { Change in } \\
\text { Pulse Rate }\end{array}$ & $\begin{array}{l}\text { Rise in } \\
\text { B.P. }\end{array}$ & $\begin{array}{l}\text { Time of } \\
\text { Rise* }^{*}\end{array}$ & $\begin{array}{l}\text { Change in } \\
\text { Pulse Rate }\end{array}$ \\
\hline 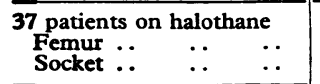 & $\begin{aligned} & 10 \pm 10 \\
& 75\end{aligned}$ & $\begin{array}{c}92 \pm 75 \\
127 \pm 161\end{array}$ & $\begin{array}{l}-3 \\
-2\end{array}$ & $\begin{array}{r}13 \pm 13 \\
9 \pm 10\end{array}$ & $\begin{array}{l}370 \pm 189 \\
413 \pm 204\end{array}$ & $\begin{array}{l}+2 \\
+1\end{array}$ \\
\hline $\begin{array}{l}13 \text { patients with neuro- } \\
\text { leptanaesthesia and } \\
\text { controlled ventilation } \\
\text { Femur } \\
\text { Socket } \\
\begin{array}{l}\text { Sock } \\
\text {. }\end{array}\end{array}$ & $\begin{array}{l}13 \pm 11 \cdot 0 \\
12 \pm 8 \cdot 9\end{array}$ & $\begin{array}{l}86 \pm 126 \\
33 \pm 36\end{array}$ & $\begin{array}{r}0 \\
-2\end{array}$ & $\begin{array}{l}22 \pm 9 \cdot 1 \\
23 \pm 18\end{array}$ & $\begin{array}{l}307 \pm 125 \\
445 \pm 164\end{array}$ & $\begin{array}{l}+7 \\
+2\end{array}$ \\
\hline $\begin{array}{l}\text { patients with subcapital } \\
\text { fracture of femur }\end{array}$ & $11 \cdot 0 \pm 5 \cdot 4$ & $28 \cdot 0 \pm 15 \cdot 2$ & -8 & $15 \pm 26$ & $159 \pm 125$ & -4 \\
\hline
\end{tabular}

*Times of lowest and highest B.P. given in seconds from the start of insertion of cement.

finding, however, was the fact that in six out of eight cases halothane had to be withdrawn from the anaesthetic before the surgical procedure began because of its effect on the blood pressure. Any potentially hypotensive anaesthetic agent must be used cautiously in these elderly patients, as the implantation of acrylic may then be an added risk.-We are, etc.,

DeREK CADle

M. L. JAMES

R. S. M. LING

R. F. PIPER

D. L. PRYer

C. C. WIIMSHURST

Princess Elizabeth Orthopaedic Hospital,

Exeter

1 Phillips, H., Cole, P. V., and Lettin, A. W. F., British Medical fournal, 1971, 3, 460.

Peebles, D. J., Ellis, R. H., Stride, S. D. K. and Simpson, B. R. J., British Medical fournal,

3 Ellis, R. 1 ${ }^{349}$., and Mulvein, J., British Medical Fourmal, 1972, 2, 528.

Phillips, H., and Dandy, D., British Medical

\section{Methylmethacrylic Cement and} Fat Embolism

SIR,-Professor J. Hume Adams and others (23 September, p. 740) report fat embolism and cerebral infarction after the use of methylmethacrylic cement in Shiers's arthroplasty of the knee. This is the third recent report of fat embolism from cement. 12 This underlines the importance of the complication. Gresham and his colleagues ${ }^{1}$ even suggest that until acceptable prophylactic measures can be devised internal fixation may be preferable in the treatment of acute fractures of the femoral neck.

The possible importance of reducing intramedullary pressure by venting the shaft of the femur has been recognized, but $I$ have found no reference to the obviois precautionary measure of sucking out all the fat before insertion of the cement. I have adopted the practice of disconnecting the sucker from the tube and passing the tube right down the reamed out bony cavity before inserting the cement. I have found that a large quantity of fat can usually be aspirated. No cases of fat embolism or circulatory collapse have been observed in patients treated in this way.-I am, etc.,

Bridgend General Hospital,

A. W. FOWLER

Glamorgan

1 Gresham, G. A., Kuczyński, A., and Rosborough, 2 Devitt, S., British Medical fournal, 1972, 2, 257

\section{Asthma and the Anxious Child}

SIR,-The articles on school refusal by $\mathrm{Dr}$ Lionel Hersov (8 July, p. 102), and the anxious child by Dr. Anne Bolton (6 September), serve to emphasize the benefits of child psychiatry in a variety of situations. Nevertheless, I was struck by the omission of any reference to asthmatic children by both authors. Few would deny that there are many emotionally-disturbed asthmatic children. It is possible that psychotherapy is being neglected in the treatment of these patients?

Current modes of therapy for asthmatics aim at symptomatic relief from attacks and the removal of "intrinsic" or "extrinsic" pathogens. Little or no attention is paid to the underlying cause for the potential to exhibit asthma. I believe that psychological factors play a major role in the priming of an asthmatic subject and deserve far more attention than they receive. To be fair, it is indeed difficult to determine whether anxiety in an asthmatic is a cause or effect of the disease. However, by a slightly teleological approach to the problem perhaps an answer can be found.

Briefly, I should like to suggest that it is the coincidence of "intrinsic" and "extrinsic" factors in a child which results in asthma that may develop as a learned response to other forms of stress. Thus anxiety in an atopic subject leads to asthma which may then be precipitated by a host of other stimuli-physical, allergic, or psychological If this is true, and asthmatic children develop symptoms originally as a means of resolving some emotional conflict, one must query why other children with similar disturbances do not develop asthma. It is my contention that the latter group show an inability to react to "extrinsic" stimulithat is, they would exhibit asthma if they could. Thus one would expect to find a lower incidence of allergic disease in this group when compared with normal children. Atupy would represent an enhanced potential for the presentation of asthma. Are there any non-asthmatic anxious children who have raised serum IgE levels?

I am not in a position to answer these questions. Perhaps someone else can help. What is obvious though is that, cause or effect, anxiety is very much involved with asthma and should be treated on a par with bronchoconstriction. It is time the psychotherapist's "hot air" was given the same regard as the physician's "aerosol."-I am, etc.

East Birmingham ifosp:tal,

A. W. WEBSter

Birmingham

Large-bowel Cancer after Previous Surgery

SIR,-We have recently undertaken a largescale investigation into the clinical history of some 600 patients with various largebowel disorders, and though the detailed findings of this survey are still unreported one rather puzzling and disquieting feature of our results perhaps merits comment at this stage.

The survey in question includes some 181 patients with large-bowel cancer, and in perusing the clinical history of these 181 patients we find that some 70 in all $(38.7 \%$ of the total) had undergone previous abdominal surgery for a variety of other complaints. Some operations were minor ones, such as 14 appendicectomies. But some 40 patients $(22.1 \%)$ had undergone major pelvic surgery and of the 87 female patients with large-bowel cancer no fewer than $23(26.4 \%)$ had had previous major gynaecological operations. Without having conducted any detailed comparisons it seems to us inconceivable that these proportions are representative of findings in a matched sample of the general population. Moreover, when we compare age distributions in our cancer patients we find that in the group with previous operations carcinoma is twice as likely to develop before the age of 50 years.

We might perhaps have written off the findings as due to chance or have ascribed them to an unrepresentative sample of patients presenting to a specialized unit, but in this connexion it is interesting to read that Clark and Jones ${ }^{1}$ noted (without comment) that a similar proportion (79 out of 228 cases $(34.6 \%)$ ) of large-bowel cancer patients in their New Zealand series had undergone previous abdominal operations We would be interested to inquire whether any other groups of workers have noted comparable findings, and if other workers can see beyond our own immediate and perhaps facile inclination to suggest that lower abdominal surgery and subsequent development of large-bowel cancer are in some way interconnected.-We are, etc.,

J. R. STANILAND F. T. DE DOMBAL

University Department of Surgery,

General Infirmary,

1 Clarke, A. M., and Jones, I. S. C., New Zealand Medical fournal, 1970, 71, 341 .

\section{Screening for Malignant Hyperpyrexia}

SIR,-The study by Dr. F. Richard Ellis and his colleagues (2 September, p. 559) on the screening of relatives of patients who have suffered from malignant hyperpyrexia is extremely important. It extends previous studies showing that a number of such relatives have raised serum creatine kinase activities. ${ }^{2}$ They show that it is possible in a number of such relatives to detect subclinical abnormalities, both histological and functional, in the muscle. By inference those with these abnormalities or with a raised creatine kinase activity would be liable to develop malignant hyperpyrexia if exposed to general anaesthetic agents. They found at least one relative with a normal serum creatine kinase activity whose muscle was morphologically and functionally abnormal.

However, the matter is clearly more complicated than indicated by their results. We have undertaken an investigation of two families with members who have suffered from malignant hyperpyrexia and rigidity, using essentially identical methods to those described by Ellis and his colleagues. The results are set out in the accompanying 


\begin{tabular}{|c|c|c|c|c|c|c|c|c|}
\hline \multirow[b]{2}{*}{$\begin{array}{l}\text { Case } \\
\text { No. }\end{array}$} & \multirow[b]{2}{*}{ Family } & \multirow{2}{*}{$\begin{array}{l}\text { Relationship } \\
\text { to Case of } \\
\text { Malignant } \\
\text { Hyperpyrexia }\end{array}$} & \multirow{2}{*}{$\begin{array}{c}\text { Relevant } \\
\text { Neurological } \\
\text { Symptoms }\end{array}$} & \multirow[b]{2}{*}{$\begin{array}{l}\text { Myopathic } \\
\text { Signs }\end{array}$} & \multirow{2}{*}{$\begin{array}{l}\text { Serum } \\
\text { C.K.K. } \\
\text { IU } / \mathbf{l} .\end{array}$} & \multirow{2}{*}{$\begin{array}{c}\text { Histological } \\
\text { Evidence } \\
\text { of } \\
\text { Myopathy }\end{array}$} & \multicolumn{2}{|c|}{ Muscle Contracture in vitro } \\
\hline & & & & & & & $\begin{array}{c}\text { Halothane } \\
\text { alone }\end{array}$ & $\begin{array}{l}\text { Halothane and } \\
\text { Suxamethonium }\end{array}$ \\
\hline $\begin{array}{l}1 \\
2 \\
3 \\
4 \\
\end{array}$ & $\begin{array}{c}\text { McP } \\
\text { " } \\
\# \\
\end{array}$ & $\begin{array}{l}\text { Father } \\
\text { Uncle } \\
\text { Uncle } \\
\text { Aunt } \\
\end{array}$ & $\begin{array}{l}- \\
\overline{-} \\
\end{array}$ & $\begin{array}{l}- \\
- \\
-\end{array}$ & $\begin{array}{r}120 \\
71 \\
972 \\
176 \\
\end{array}$ & $\begin{array}{l}- \\
- \\
-\end{array}$ & $\begin{array}{l}- \\
+ \\
\end{array}$ & $\underline{-}$ \\
\hline $\begin{array}{l}5 \\
6\end{array}$ & $\begin{array}{c}\mathbf{H} \\
\text { " }\end{array}$ & $\begin{array}{l}\text { Father } \\
\text { Uncle }\end{array}$ & $\overline{-}$ & - & $\begin{array}{r}178 \\
95\end{array}$ & $\overline{-}$ & $\overline{-}$ & - \\
\hline
\end{tabular}

*Normal upper limit (mean + 2 S.D.) 75 IU/1.

Table. All but one patient had a raised serum creatine kinase activity. The patient with a normal creatine kinase activity had two daughters with raised activities of 101 and 93 IU, and by inference was concluded to be carrying the gene for malignant hyperpyrexia. None of the biopsies showed definite histological evidence of myopathy, and only one developed contracture when exposed to halothane in vitro. This patient had the highest creatine kinase activity of 972 IU. Halothane potentiated the caffeine-induced contracture of the muscle in vitro to a similar extent to that seen in normal muscle.

It is interesting that two of these patients had undergone general anaesthesia-Case 2 for removal of a fractured patella and Case 4 for dilatation and curettage. Unfortunately the anaesthetic agents used were not recorded in the notes in either case. The differences between the findings of Ellis and his colleagues and ourselves supports the suggestion that several different metabolic abnormalities may underlie the syndrome of malignant hyperpyrexia. King and others ${ }^{3}$ have separated six possible clinical subgroups from families with this condition.

We conclude that further studies are required to define which is the best method of detecting potentially susceptible relatives. At present we are investigating the use of the quantitative electromyogram, since this has been abnormal in some of these patients. The advice to relatives of a patient who has suffered from malignant hyperpyrexia should lean to the conservative side. If an abnormality is found in any of the specific tests the patient should be advised never to have a general anaesthetic. Even when all investigations are normal it is stiil impossible to guarantee that the patient is free of risk from a general anaesthetic, and even these patients should be strongly advised against general anaestheisa.-We are, etc.,

W. G. BRADLEY

DOROTHY MURCHISON

Newcastle General Hospital

Nevicastle upon Tyne

1 Denborough, M. A., Ebeling, O., King, J. O., and 2 Zapf, P., Lancet, 1970, 1, 1137. 2 Isaacs, H., and Barlow,

3 King, J. O., Denborough, M. A.. and Zapf,

\section{Chronic Gastric Ulcers}

SrR,-Your review (16 September, p. 659) of the Veterans Administration study on gastric ulcer $^{1}$ ended on an optimistic note which might at this stage be a little premature. Having pointed out that one in 25 patients thought to have a benign ulcer will have gas'ric cancer, you suggested that gastroscopic biopsy might help in detection of such malignancy. Unfortunately, in practice, this has not proved to be true.
In a recent review of 140 gastroscopies carried out for a variety of reasons, using an Olympus G.F.B. gastroscope with biopsy attachment, 24 patients had biopsies taken of the edge of a chronic gastric ulcer Gastroscopically 23 of these ulcers appeared benign. Only one biopsy was reported as showing malignant change. Fourteen of these patients had surgical treatment for their ulcers (13 had a partial gastrectomy and one a vagotomy, pyloroplasty, and open biopsy). No fewer than three ulcers were found on subsequent histological examination to be malignant. Thus gastric biopsy had failed to demonstrate two out of three malignant ulcers.

There are two reasons for this failuretechnical and biological. Gastroscopic biopsy forceps are small and blunt, only small fragments of tissue can be obtained, and it can be difficult to get the forceps to bite on the edge of an indurated chronic ulcer. Secondly, malignant change may not always be present throughout the whole of an ulcer. In open operation it is usually regarded as mandatory to take four-quadrant biopsies. This can be difficult at gastroscopy, and the appropriate part of the ulcer may be missed. Thus while a positive biopsy is of undoubted value a negativ - Fort could be dangerously misleadif - We are, etc.

P. Goodall

Derbyshire Royal Infirmary,

J. Cockrp year.

Derby

1 Veterans Administration Co-operative Study on 4astric Ulcer,

\section{Detecting Sickle Haemoglobin}

SIR,-Professor J. E. Bowman (9 September, p. 644) warns your readers that solubility tests used on their own give inadequate information, especially for genetic counsel-

ling. Your leading article (29 April, p. 246) never advised, however, their use for this purpose, merely pointing out their value in population screening. Professor Bowman also felt that the leading article had not drawn attention to the inadequacies of a solubility test which "allegedly differentiates $\mathrm{Hb}$ AS and Hb SS genotypes." This test ${ }^{1}$ was devised as a rapid screening test for patients prior to surgery and its limitations were then fully discussed. For example, in the original paper it was pointed out that the sickle-cell trait would give a similar result to sickle-cell haemoglobin $\mathrm{C}$ disease, but that in the emergency situation these two conditions may usually be differentiated by examining a blood film. Both in the body of the text and in the synopsis emphasis is laid on further investigation (which would include electrophoresis) as soon as routine laboratory facilities were available.

The information given to the anaesthetist and the surgeon during the night hours must of necessity be different from the exact diagnosis demanded by the genetic counsellor. In the latter circumstances, Professor Bowman rightly states, electrophoresis and solubility tests must be combined. However it would be a pity if a solubility test fell into general disrepute because it was condemned as unsuitable when used as the sole diagnostic test prior to genetic counselling-a use which was never envisaged by the authors.

Both the reliability of the solubility test in detecting sickle-cell haemoglobin and its ability to differentiate sickle-cell haemoglobin $G$ disease from sickle-cell anaemia ${ }^{2}$ suggest it has a place not only when used on its own in an emergency procedure but also when combined with electrophoresis in a laboratory providing diagnostic information to the genetic counsellor.-I am, etc.,

\section{R. G. Huntsman}

Lambeth Hospital,

London S.E.11

1 Huntsman, R. G., Barclay, G. P. T., Canning, D. M., and Yawson, G. I., fournal of Clinical Pathology, 1970, 23, 781.

fournal of Clinical Pathology, 1972, 58, 11 .

\section{Screening for Thalassaemia Trait}

SIR,-In their article on the incidence of thalassaemia trait among cypriots in London (23 September, p. 737) Dr. C. B. Modell and others advocate the screening of Cypriot school leavers for thalassaemia trait. Acting on the advice of Dr. I. Wickes, formerly consultant paediatrician at the North Middlesex Hospital, the screening of appropriate school leavers from the Mediterranean countries both for thalassaemia trait and for sickle-cell trait was started in the London borough of Enfield in April this

At their final school medical examination a brief explanation is given to the children concerned and a letter sent home to their parents, advising a screening test. This is carried out in the haematology department of the North Middlesex Hospital and the parents and family doctors are notified of the results. In cases where thalassaemia trait or sickle-cell trait is found further explanation and advice are offered. It is hoped in due course to produce a report, together with the consultants concerned, on the results of this screening procedure.-I am etc.,

L. Crawford

School Health Department,

Enfield, Midd

\section{Rehabilitation}

SIR,-Rehabilitation as a discipline of medicine is perhaps unique in not being fundamentally concerned with clinical entities, physical signs, pathology, or even therapeutics. Rehabilitation is concerned with function, and must be judged by how its methods affect the performance both socially and economically of those to whom it is applied. Disability may be progressive, permanent, or temporary. Rehabilitation methods may need to differ considerably in these three groups, and certainly the aims may differ widely. This in fact is the nub of the problem. 